\title{
The influence of canopy-layer composition on understory plant diversity in southern temperate forests
}

\author{
Luciana Mestre*, Mónica Toro-Manríquez, Rosina Soler, Alejandro Huertas-Herrera, Guillermo Martínez-Pastur \\ and María Vanessa Lencinas
}

\begin{abstract}
Background: Understory plants represents the largest component of biodiversity in most forest ecosystems and plays a key role in forest functioning. Despite their importance, the influence of overstory-layer composition on understory plant diversity is relatively poorly understood within deciduous-evergreen broadleaved mixed forests. The aim of this work was to evaluate how tree overstory-layer composition influences on understory-layer diversity in three forest types (monospecific deciduous Nothofagus pumilio (Np), monospecific evergreen Nothofagus betuloides (Nb), and mixed N. pumilio-N. betuloides (M) forests), comparing also between two geographical locations (coast and mountain) to estimate differences at landscape level.
\end{abstract}

Results: We recorded 46 plant species: 4 ferns, 12 monocots, and 30 dicots. Canopy-layer composition influences the herb-layer structure and diversity in two different ways: while mixed forests have greater similarity to evergreen forests in the understory structural features, deciduous and mixed were similar in terms of the specific composition of plant assemblage. Deciduous pure stands were the most diverse, meanwhile evergreen stands were least diverse. Lack of exclusive species of mixed forest could represent a transition where evergreen and deciduous communities meet and integrate. Moreover, landscape has a major influence on the structure, diversity and richness of understory vegetation of pure and mixed forests likely associated to the magnitude and frequency of natural disturbances, where mountain forest not only had highest herb-layer diversity but also more exclusive species.

Conclusions: Our study suggests that mixed Nothofagus forest supports coexistence of both pure deciduous and pure evergreen understory plant species and different assemblages in coastal and mountain sites. Maintaining the mixture of canopy patch types within mixed stands will be important for conserving the natural patterns of understory plant composition in southern beech mixed forests.

Keywords: Landscape, Understory communities, Understory structure, Forest structure, Nothofagus, Conservation

\section{Background}

The understory is a critical feature of forest ecosystems, which affects energy flow and nutrient cycling, biodiversity and regeneration capacity (Gilliam 2007). Also, understory responds fast to both natural and anthropogenic disturbances (Lencinas et al. 2011), e.g. avoiding erosion and generating suitable microenvironments for other species development (Simonson et al. 2014). However, understory

\footnotetext{
* Correspondence: lucianamestre@hotmail.com

National Scientific and Technical Research Council (CONICET), Austral Center for Scientific Research (CADIC-CONICET), Houssay 200, 9410 Ushuaia, Tierra del Fuego, Argentina
}

plants have heterogeneous composition, structure and distribution patterns, which depend on the overstory species, forest structure, micro-environmental and stand conditions (e.g., Márialigeti et al. 2016; Tinya and Ódor 2016). Moreover, understory could provide habitat and resource specificity to sustain rare or exclusive species in the herbaceous layer, which have excellent potential for use as biodiversity indicators (Spyreas and Matthews 2006). Thus, several forest understory species are well-known indicators of site conditions, impact of forest management and effects of climate change (Gracia et al. 2007; Chavez and Macdonald 2012), and could act as a useful indicator 
of forest sustainability, ecosystem health and conservation status (Dale et al. 2002; Lencinas et al. 2008a; Chavez and Macdonald 2012).

Temperate forest is a worldwide distributed biome that usually exhibit strong seasonality, favoring those plant and animal species that were able to adapt to short-term climatic variation (Dreiss and Volin 2013). In temperate deciduous forests, trees drop their leaves in autumn allowing high seasonal variation in light availability for the understory; while in evergreen broadleaved forests -more commonly found in the Southern Hemisphere- trees keep their leaves year round, therefore understory plants are adapted to low light availability in all seasons. In both broadleaved forest types, understory plants have adapted to maximize their light/energy capture in different ways. Kudo et al. (2008) found that some understory plants inhabiting deciduous stands complete most of their annual growth cycle in the few weeks between snowmelt and the closure of the tree canopy. Meanwhile shaded plants inhabiting evergreen broadleaved forests tend to allocate more growth to leaves, displaying larger, thinner leaves which take up more horizontal area for light capture (Damascos 1996; Promis et al. 2008). Even the most shade-intolerant species may disappear completely in pure evergreen stands developing a forest typical climax shade-tolerant species. However, there is little information about particularities of understory composition, structure and distribution patterns in mixed deciduous-evergreen broadleaved forests (see Kuninaga et al. 2015).

Magellanic forests, one of the most pristine areas in the world (Mittermeier et al. 2003), are conformed mainly by Nothofagus tree species, of which deciduous $N$. pumilio had a wide distribution range and dominates inner the main island of the Archipelago of Tierra del Fuego, while evergreen $N$. betuloides develops in softer environmental conditions, as in a middle altitude on the mountain valleys, or next to the Beagle Channel and big lake coasts (Allué et al. 2010). In a narrow area of their distribution range in the archipelago, $N$. betuloides grows together with $N$. pumilio forming a mixed deciduous-evergreen forest (Tuhkanen 1992), in the two both predominant landscapes where $N$. betuloides occurred (coast and mountains). Mixed forests of N. pumilio and N. betuloides also occurred in mild climate zones of the continent, for which the distribution and dominance of vascular plant species in the understory has been barely described (Veblen et al. 1978, 1979; Cruz et al. 2007). Contrary, in the southernmost island conditions, understory composition and structure of mixed deciduous-evergreen Nothofagus forests have been little explored (Promis et al. 2008) compared to pure Nothofagus forests. Many researches in $N$. pumilio were developed studying natural unmanaged and several anthropogenic impacted forests (e.g., Martínez Pastur et al. 2002; Lencinas et al. 2008a, 2008b, 2011), but pure $N$. betuloides forests have received fewer attention. Both pure forest types usually develop a sparse and short understory layer (less than $1 \mathrm{~m}$ tall), mainly conformed by herbaceous and moss species (Moore 1983; Matteri and Schiavone 2002). But differences and similarities in understory composition and structure among pure and mixed Nothofagus forests are still unknown. Therefore, in this work we evaluate the influence of canopy-layer dominance (deciduous, evergreen, and mixed deciduous-evergreen) from old-growth Nothofagus forests on understory structure (frequency, cover, sub-layers), and vascular plant composition (richness and pattern assemblage), at two typical landscape locations (coast and mountain) of their natural distribution on Tierra del Fuego Island.

We hypothesize that: (i) the composition and structure of understory in mixed forests includes characteristics of both pure forest types, being structurally similar to any of these two, and reaching greater species richness in mixed compared to pure forests; (ii) differences and similarities among pure and mixed forest are maintained in different landscape locations (coast-mountain) although the specific composition of vascular plants could vary between such locations; (iii) pure forests had high number of exclusive plant species (e.g., shade tolerant species) compared to mixed forest, which can be considered indicator species of each canopy composition (deciduous or evergreen) and landscape locations (coastal or mountain sites). Understanding the influence of tree canopy-layer composition on the distribution of understory plants is important for biological conservation in these southern-beech forests. Moreover, in a possible scenario of global climate change mixed-species forests have been put forward as important risk reduction and adaptation strategies for environmental stress conditions (Forrester et al. 2016).

\section{Method \\ Study site description}

Native forests in Tierra del Fuego Island occupy more than 30\% surface from inner mountains to Beagle Channel coasts (Allué et al. 2010). At this latitude, these forests grow naturally under extreme environmental conditions as the climate is strongly influenced by oceanic current, Antarctica proximity but also the Andes Mountains (Kreps et al. 2012). Climate is characterized by short, cool summers and long, snowy winters with frequent occurrence of frosts. Only three months per year have daily temperature above $0^{\circ} \mathrm{C}$, and the growing season extends approximately from November to March. Mean monthly temperatures vary from $-7^{\circ} \mathrm{C}$ to $14^{\circ} \mathrm{C}$ (extremes vary from $-17^{\circ} \mathrm{C}$ in July to $22^{\circ} \mathrm{C}$ in January) and precipitations reaches up to $600 \mathrm{~mm} \cdot \mathrm{year}^{-1}$. Annual wind speed outside forests is $8 \mathrm{~km} \cdot \mathrm{h}^{-1}$ in average, reaching up to $100 \mathrm{~km} \cdot \mathrm{h}^{-1}$ during storms. The wind storms and the avalanches are the most 
common natural disturbances causing tree blown-down in small and large areas (Martínez Pastur et al. 2011; Kreps et al. 2012).

The study was carried out in mature mixed Nothofagus forests (>250 years) located south-west of Tierra del Fuego Island, Argentina (Fig. 1), without previous timber management in the last 50 years. Three Nothofagus forests situations were considered according to their canopy-layer composition: (1) pure deciduous forests with $>80 \% \mathrm{~N}$. pumilio crown cover; (2) pure evergreen forests with $>80 \%$ $N$. betuloides crown cover; and (3) mixed N. pumilio-N. betuloides forests, with similar proportions of both species in the canopy. Likewise, two landscape locations were selected where these three forest types could be found: coast close to the Beagle Channel, and mountain toward the inner island. The coast sites were placed within the Tierra del Fuego National Park where the altitude is $50-100 \mathrm{~m}$ a.s.l.; the mean annual temperature varies between $2.1^{\circ} \mathrm{C}$ and $10.9^{\circ} \mathrm{C}$ and accumulated rainfall is $710 \mathrm{~mm} \cdot \mathrm{year}^{-1}$ with abundant snow fall (Kreps et al. 2012). Meanwhile, mountain forest sites were located through Garibaldi Pass in last foothills of the Andes Mountain Range where the altitude is $300-350 \mathrm{~m}$ a.s.l.; mean annual temperature varies between $-0.6^{\circ} \mathrm{C}$ and $7.2^{\circ} \mathrm{C}$ and accumulated rainfall is 545 $\mathrm{mm} \cdot \mathrm{year}^{-1}$ (Kreps et al. 2012).

\section{Forest structure characterization}

Forest structure was characterized by angle-count sampling plots ( $n=10$ for each forest type and location, $N=60$ ) following Bitterlich (1984). To apply this methodology we used a Criterion RD-1000 (Laser Technology, USA) with a variable basal area factor $(\mathrm{K})$ between 6 or 7 , which allowed to recording tree basal area (BA) and density (N). Additionally, dominant height (DH) was estimated using a TruPulse 200 laser clinometer and distance rangefinder (Laser Technology, USA) by averaging height of the three taller trees per plot. Also, species and diameter at breast height (MD) was determined for each tree included in each plot. These data were collected between October and December 2012.

Above the center of each forest plot, hemispherical photos of the canopy were taken. We used an $8 \mathrm{~mm}$ fisheye lens (Sigma Ex-AF4, Japan) mounted on a $35 \mathrm{~mm}$ digital camera (Nikon D50, Japan) with a tripod and level and they were oriented to magnetic north. The camera was set $1 \mathrm{~m}$ above the ground. This height is enough to avoid registering understory or shrub cover, and only register tree canopy cover. The program Gap Light Analyzer v2.0 0 (Frazer et al. 2001) was used to calculate canopy cover (CC) as a percentage, direct (RDR) and diffuse (RDF) solar radiation transmitted through canopy, and total radiation ratio (RT) (direct plus diffuse radiation transmitted through canopy, related to total radiation incident on a horizontal surface located above forest canopy). This data was obtained by taking just one photo per plot in January-February 2013 (summer in South Hemisphere) avoiding the influence of direct sun light. The program offers the total value of RDR, RDF and RT for each month along the whole year, which are based on latitude and longitude, as well as cloudy index of each specific location. For details of inputs and models see Martínez Pastur et al. (2011). In our work, we averaged the values of the growing season (September to April).

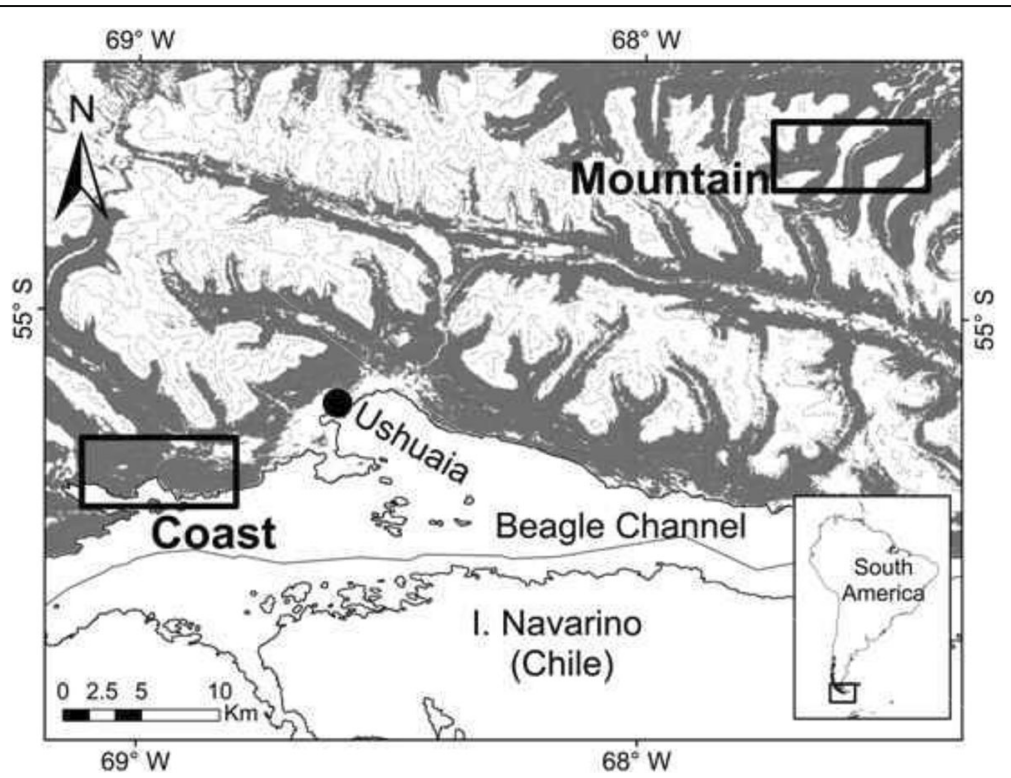

Fig. 1 Location of study area in south-west Argentinean Tierra del Fuego. Rectangles indicate sampling locations: on the coast of the Beagle Channel (54 $50^{\prime} 29^{\prime \prime} \mathrm{S}$ and $\left.68^{\circ} 31^{\prime} 54^{\prime \prime} \mathrm{W}\right)$ and on the Andean Mountains region (54 $41^{\prime} 05^{\prime \prime} \mathrm{S}$ and $\left.67^{\circ} 48^{\prime} 10^{\prime \prime} \mathrm{W}\right)$ 


\section{Understory structure and composition}

To evaluate the understory structure and composition we established two linear transects (10 m length each) associated to each forest structure plot $(n=10$ for each forest type and location, $N=60$ ). Transects were located parallel and $5 \mathrm{~m}$ apart, one from each other, and then averaged. We used the point-intercept method (Brancaleoni et al. 2003) completing 50 intercept points per transect (every $20 \mathrm{~cm}$ ) to record vascular plant species richness (calculated at the transect level) and ground cover by species and types (bare soil, debris and vegetation, which was differentiated in lichens, bryophytes, dicots, monocots and ferns). Cover was estimated by sub-layers (top or dominant layer, down or suppressed layer), and total (dominant plus suppressed sub-layers). We then calculated the number of layers at each intercepting point. Vascular plants (dicots, monocots and ferns) were taxonomically determined and classified by their origin (native or exotic) and life form (trees, shrubs, prostrate herbs, erect herbs, rhizomatous grasses and caespitose grasses) following Moore (1983) and Correa (1969-1998). Occurrence frequency for each species by forest type is shown in Additional file 1. We could not differentiate species of bryophyte and lichens so both of them were considered at group level. Bare soil refers to forest soil (including rocks) usually cover by litter but without vegetation. Debris included branches and trunks more than $3 \mathrm{~cm}$ in diameter. Also, an understory "dominance index" was calculated for each cover type (bare soil, debris, lichens, bryophytes, ferns, monocots and dicots), dividing each dominant cover type by total cover at each transect, and then the results were expressed as percentage. Fieldwork was conducted during January-February 2013 (summer in South Hemisphere). This period is considered the most appropriated to conduct vegetation surveys in Nothofagus forests at this latitude to record all plant species inhabiting the understory layer and to avoid neglect species as can occur before or after that date within the growing season (Lencinas et al. 2008a). The short duration of the growing period and the hard climate conditions influence on growth and develop of understory plant species to better express them (vegetative and reproductively) in this period. Juvenile trees (seedlings and saplings of $N$. pumilio and $N$. betuloides less than $0.5 \mathrm{~m}$ height) were also included as understory components.

\section{Data analysis}

Forest and understory structure variables were analyzed using a two-way ANOVA design, in which the forest type (three levels: deciduous, mixed, evergreen) and landscape location (two levels: coast, mountain) were the main factors of analysis. Likewise, structure differences between overstory species were compared in mixed forests, using also two-way ANOVAs, where species (two levels: N. pumilio, $N$. betuloides) and landscape location (two levels: coast, mountain) were the main factors of analysis. Variables were $\ln (Y)$ or $\ln (Y+1)$ transformed for the analysis to accomplish statistical ANOVA assumptions, but not transformed mean values are shown in Tables. The comparisons of mean values were done using the Tukey honestly significant difference test $(p<0.05)$. Statistically significant interactions were plotted to get a better interpretation of our results.

Complementary, four multivariate methods were applied: (i) a non-metric multidimensional scaling (NMS) ordination, with 9999 unrestricted random permutations of the raw data, (ii) a multi-response permutation procedures (MRPP), both based on Bray-Curtis (Sørensen) distance; (iii) a detrended correspond analysis (DCA) with down weighting of rare species and axes rescaling; and (iv) an Indicator Species Analysis (IndVal), including a random reallocation procedure with 4999 permutations (Monte Carlo test) to evaluate the significance of the maximum IndVals $(p<0.005)$. All the multivariate analysis were conducted with species abundance (intercepted species in transects).

NMS and MRPP were jointly used to assess similarity or difference of understory composition among forest types and locations, and support the visual assessment of these patterns. DCA allows evaluating differential botanical composition of each forest type. IndVal was useful to determine whether any species could be associated with certain habitats or treatments (Dufrêne and Legendre 1997). All multivariate methods were performed using vascular plant species cover, but NMS and MRPP also included general ground cover types (bare soil, debris, lichens and bryophytes) in the matrix.

In MRPP, within-group homogeneity is measured as the chance-corrected within-group agreement (A): when all items are identical within groups, then $A=1$ (perfect association); when heterogeneity within groups equals expectation by chance, then $A=0$ (no association between sample units and defined groups); when there is less agreement within groups than expected by chance, then $A<0$ (McCune and Grace 2002). On the other hand, IndVal varied between 0 (no indication) and 100 (perfect indication), being highest when all individuals of a species are found in a single habitat (high specificity) and the species occurs in all samples of that habitat (high fidelity). Species with IndVal greater than 50 and $p$ values lower than 0.05 can be considered as "indicator species" (characteristic species of a particular site or condition), while species with IndVal between 25 and 50 and $p$ values lower than 0.05 can be considered as "detector species" (provide information from more than one habitat, and indicate the change direction in the habitat quality) (TejedaCruz et al. 2008). IndVal tests were performed for each forest type and location, jointly and separately. We used the software PC-ORD (Bruce and Mefford 1999) to conduct all multivariate analyses. 


\section{Results}

\section{Forest structure}

Forest structure showed significant differences among forest types and locations (Table 1). Deciduous forests had significantly fewer tree density and higher dominant height and mean diameter than evergreen forests. Mixed forests did not differentiate from evergreen forests in tree density and dominant height, while they differed from both deciduous and evergreen forests in mean diameter. On the other hand, canopy cover and basal area were significantly higher in mountain than in coastal sites, while differences were not significant between locations for the other variables. There were significant interactions for the basal area and direct solar radiation (Fig. 2). Interactions in basal area occurred due to in coastal sites all forest types had similar values while in mountain sites deciduous stands had significant lower basal area than mixed and evergreeen stands. At the same time, basal area of coastal and mountain locations differed only in mixed forests. Interactions for direct solar radiation occurred due to in mountain sites all forest types had similar values while in coastal sites mixed stands showed significantly higher values than deciduous and evergreen stands. And simultaneously, significant differences between locations occurred only in deciduous forests (Fig. 2).

The tree-layer of deciduous forest was $100 \%$ N. pumilio trees, while evergreen forests had 92\% BA of $N$. betuloides and $8 \%$ of $N$. pumilio. The tree-layer of mixed forests had $67 \%$ trees of $N$. pumilio (58\% BA) and $33 \%$ of $N$. betuloides (42\% BA) (Table 2). Basal area, dominant height and mean diameter were similar for both Nothofagus species in mixed forests, but there were significant differences for tree density and percentage of basal area (greater values for $N$. pumilio than for $N$. betuloides). Likewise, basal area, density and dominant height of mixed stands were similar between locations, but there were significant differences in mean diameter of trees (greater values in the coast than in the mountain). Also, interactions occurred due to both species had similar values in mountain sites but in coastal sites in $N$. pumilio showed greater values than $N$. betuloides, whitout significant differences between locations for each tree species.

\section{Understory richness, structure and cover}

There were observed 46 vascular plant species in the understory of deciduous, mixed and evergreen Nothofagus forests, including four ferns, 12 monocots and 30 dicots (Additional file 1). Only two species (Chiliotrichum diffusum and Taraxacum officinale) were observed but not intercepted (recorded) on transects. For this such species were included in the Annex but not in the statistical analysis. The overall richness was related to the forest type, following the order deciduous $>$ mixed $>$ evergreen, and ranging from 39 to 21 species, of which $33 \%$ of the total richness (15 species) were found in all forest types. The occurrence frequency of the three-environment-shared species was related to the forest type, being the more frequent species $N$. betuloides, Rubus geoides and Pernettya pumila in evergreen forests (with more than $70 \%$ occurrence frequency), and N. pumilio, Codonorchis lessonii and Adenocaulon chilense in deciduous forests (with more than $80 \%$ occurrence frequency). Four of these species were also the most frequent in mixed forests ( $N$. betuloides, $N$. pumilio, $C$. lessonii and $R$. geoides). The exclusive species from each forest type were seven in deciduous, three in evergreen and only one in mixed forests, while 17 species were shared between mixed and deciduos forests only, and three species between mixed and evergreen forests only. There were not species shared between pure forests only.

Likewise, richness was very similar between coast and mountain locations (33 and 36 species, respectively), and $50 \%$ of the total richness (23 species) were shared between the both locations. The more frequent shared species were $N$. pumilio in both locations, C. lessonii and $N$. betuloides in coast (with more than $67 \%$ occurrence frequency), and R. geoides and P. pumila in mountain (with more than $77 \%$

Table 1 Forest structure in Nothofagus forest of Tierra del Fuego, according to forest type (deciduous, mixed, or evergreen) and landscape location (coast or mountain)

\begin{tabular}{llllllllll}
\hline Factor & & $\mathrm{BA}\left(\mathrm{m}^{2} \cdot \mathrm{ha}^{-1}\right)$ & $\mathrm{N}\left(\mathrm{ind} \cdot \mathrm{ha} \mathrm{a}^{-1}\right)$ & $\mathrm{DH}(\mathrm{m})$ & $\mathrm{MD}(\mathrm{cm})$ & $\mathrm{CC}(\%)$ & $\mathrm{RDR}\left(\mathrm{w} \cdot \mathrm{m}^{-2}\right)$ & $\mathrm{RDF}\left(\mathrm{w} \cdot \mathrm{m}^{-2}\right)$ & $\mathrm{RT}(\%)$ \\
\hline Type & Deciduous & $66.55 \mathrm{a}$ & $380.68 \mathrm{a}$ & $21.97 \mathrm{~b}$ & $63.19 \mathrm{c}$ & 89.98 & $0.80 \mathrm{a}$ & 3.36 & 12.58 \\
& Mixed & $77.10 \mathrm{ab}$ & $909.87 \mathrm{~b}$ & $17.65 \mathrm{a}$ & $47.98 \mathrm{~b}$ & 88.32 & $1.02 \mathrm{~b}$ & 4.27 & 15.97 \\
& Evergreen & $84.50 \mathrm{~b}$ & $1238.47 \mathrm{~b}$ & $15.93 \mathrm{a}$ & $37.54 \mathrm{a}$ & 87.02 & $0.78 \mathrm{a}$ & 3.93 & 14.20 \\
& $\mathrm{~F}(p)$ & $7.12(0.002)$ & $21.36(<0.001)$ & $12.31(<0.001)$ & $33.35(<0.001)$ & $2.55(0.088)$ & $3.24(0.047)$ & $2.99(0.059)$ & $3.03(0.057)$ \\
Location & Coast & $71.37 \mathrm{a}$ & 790.02 & 18.73 & 51.73 & $87.37 \mathrm{a}$ & 0.87 & 4.08 & 14.97 \\
& Mountain & $80.73 \mathrm{~b}$ & 895.97 & 18.31 & 47.41 & $89.52 \mathrm{~b}$ & 0.86 & 3.62 & 13.52 \\
& $F(p)$ & $5.76(0.020)$ & $0.15(0.701)$ & $0.17(0.683)$ & $2.81(0.100)$ & $4.03(0.049)$ & $0.02(0.884)$ & $2.27(0.138)$ & $1.67(0.202)$ \\
Type $\times$ Location & $F(p)$ & $5.71(0.006)$ & $2.61(0.083)$ & $1.80(0.175)$ & $0.75(0.476)$ & $1.73(0.187)$ & $3.71(0.031)$ & $0.76(0.471)$ & $1.22(0.303)$ \\
\hline
\end{tabular}

The studied variables were basal area (BA), density $(\mathrm{N})$, dominant height $(\mathrm{DH})$, diameter at breast height (MD), canopy cover (CC), direct solar radiation (RDR), diffuse radiation (RDF) and total radiation ratio (RT). $N$ was In transformed to accomplish ANOVA assumptions, but not transformed data are shown $F(p)=$ Fisher statistic with probability between brackets. Different letters show differences by Tukey test at $p<0.05$ 

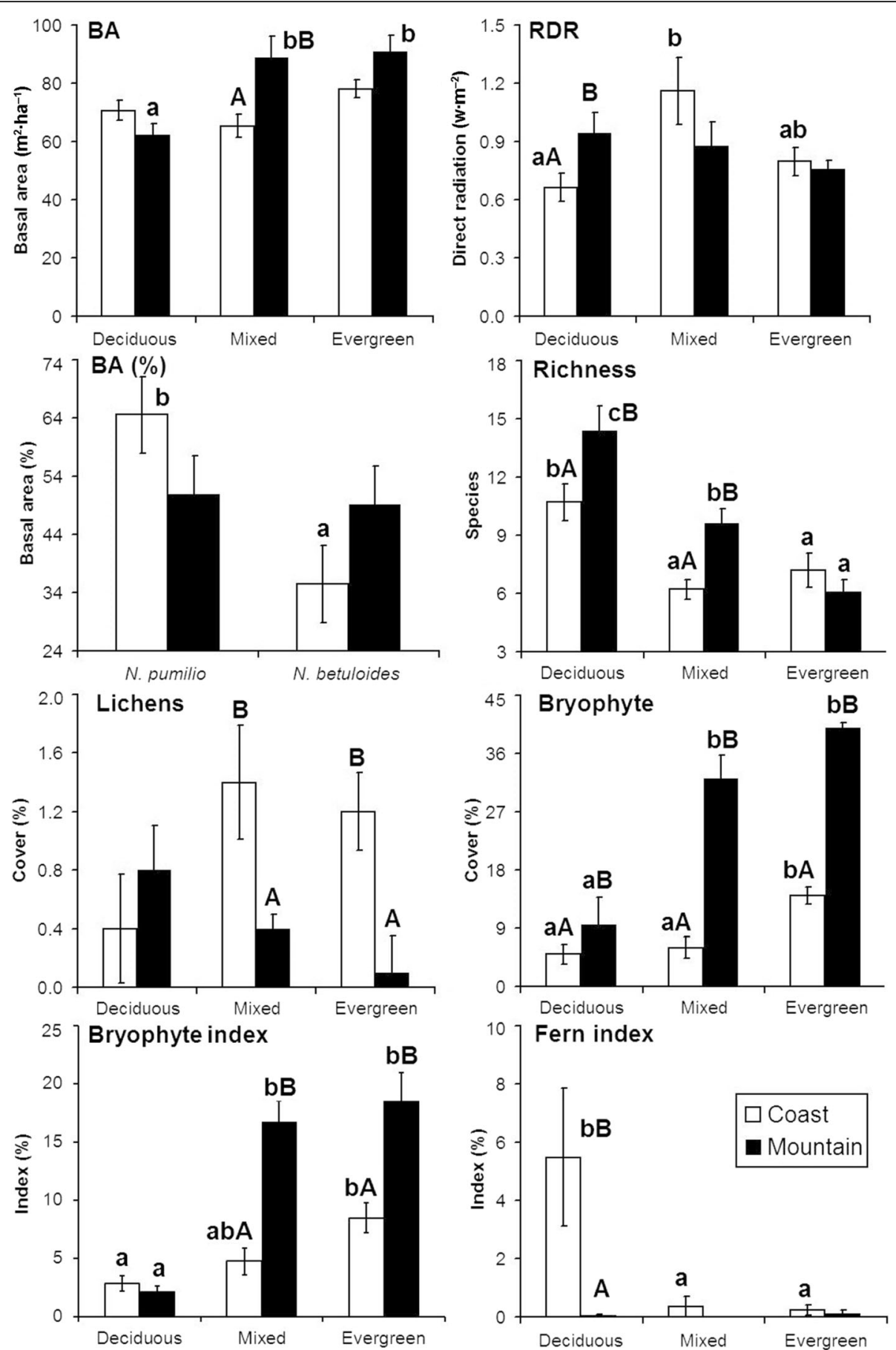

Fig. 2 Interactions corresponding to Tables 1, 2, 3, 4 and 5. For BA (basal area), RDR (direct solar radiation), Richness, Lichens and Bryophyte porcentual covers, Bryophyte and Fern understory indexes, letters indicates significant differences by Tukey test $(p<0.05)$, with small letters for comparisons among forest types (deciduous, mixed or evergreen), and capital letters for comparisons between locations (coast or mountain). For BA (\%) (proportional basal area), letters indicates significant differences by Tukey test $(p<0.05)$, with small letters for comparisons between species ( $N$. pumilio and N. betuloides). Letters are shown when differences were statistically significant.

occurrence frequency). The exclusive species from each location were 10 species in coast and 13 in mountain.

Only four of the observed vascular plants were alien species: Cerastium fontanum, Poa pratensis, Stellaria media and Taraxacum officinale (less than 10\% occurrence frequency in the whole sampling). These did not occurr in evergreen forests at all, but they did in deciduous and mixed forests (less than 20\% occurrence frequency and 1\% 
Table 2 Forest structure in mixed Nothofagus forests of Tierra del Fuego, according to species (N. pumilio and N. betuloides) and landscape location (coast or mountain)

\begin{tabular}{lllllll}
\hline Factor & & $\mathrm{BA}\left(\mathrm{m}^{2} \cdot \mathrm{ha}^{-1}\right)$ & $\mathrm{BA}(\%)$ & $\mathrm{N}\left(\mathrm{ind} \cdot \mathrm{ha}^{-1}\right)$ & $\mathrm{DH}(\mathrm{m})$ & $\mathrm{MD}(\mathrm{cm})$ \\
\hline Species & N. pumilio & 43.5 & $57.7 \mathrm{~b}$ & $682.7 \mathrm{~b}$ & 18.0 & 45.7 \\
& N. betuloides & 33.6 & $42.3 \mathrm{a}$ & $227.2 \mathrm{a}$ & 18.5 & 53.4 \\
& $F(p)$ & $2.37(0.132)$ & $5.43(0.026)$ & $9.23(0.004)$ & $0.07(0.789)$ & $2.75(0.106)$ \\
Location & Coast & 32.7 & 50.0 & 365.6 & 17.2 & $54.4 \mathrm{~b}$ \\
& Mountain & 44.4 & 50.0 & 544.3 & 9.3 & $4.7 \mathrm{a}$ \\
& $F(p)$ & $3.32(0.077)$ & $0.00(1.000)$ & $9.98(0.093)$ & $1.36(0.253)$ & $4.31(0.045)$ \\
Type $\times$ Location & $F(p)$ & $1.36(0.251)$ & $4.28(0.046)$ & $0.21(0.650)$ & $0.05(0.829)$ & $4.12(0.050)$
\end{tabular}

The studied variables were basal area (BA), density (N), dominant height (DH) and diameter at breast height (MD). N was In transformed to accomplish ANOVA assumptions, but not transformed data are shown

$F(p)=$ Fisher statistic with probability between brackets. Different letters show differences by Tukey test at $p<0.05$

cover), being found T. officinale and Cerastium fontanun in deciduous and mixed forests, S. media only in mixed forests, and Poa pratensis only in deciduous forests. On the other hand, P. pratensis were only found in coasts, S. media and T. officinale occurred only in mountains, and C. fontanum was present in both locations.

Understory structure was influenced by both forest type and landscape location (Table 3). A maximum of 18 plant species per plot and 5 vertical strata were registered, with significantly highest richness and strata quantity in deciduous forests. Interaction in richness occurred by significantly higher values in deciduos forests than in mixed and evergreen forests in coast sites (Fig. 2), while in mountain, richness significantly differed among all forest types following the gradient evergreen $<$ mixed $<$ deciduous. Likewise, mountain locations presented significantly higher richness than coast in deciduous and mixed forests, but differences were not found in evergreen forests. Also, significant differences were found in bare soil and vegetation for both forest type and location, with significantly lower bare soil and higher vegetation in deciduous forests than in mixed and evergreen, as well as in mountain than in coast location.
About cover by taxonomic groups (Table 4), fern, monocot and dicot covers were significantly higher in deciduous forests than in mixed and evergreen forests, while monocot and dicot covers were also higher in moutain than in coast locations. Interaction in lichens occurred by significantly greater cover in coast than in mountain in mixed and evergreen forests (Fig. 2), but not in deciduous one, while there were not detected statistical differences among forest types for each location. For bryophytes, interactions took place due to significantly higher cover in evergreen than in deciduous and mixed forests in coast locations (Fig. 2), but similar and higher bryophyte cover in evergreen and mixed than in deciduous forests in mountain location. Likewise, all forest types presented significantly higher bryophyte cover in mountain than in coast locations.

In relation to the understory index (Table 5), that reflects the relative dominance of each taxonomic group, dicots were dominant for all forest types and locations (percentage index $=30 \%$ in average), without significant differences among them. Bare soil was also important in mixed and evergreen forests (percentage index $=30 \%$ in average), and significatly lower in deciduos forests (percentage index $=13 \%$ ), followed by debris with also greater values in mixed and evergreen

Table 3 Understory structure (species richness, strata quantity) and general ground cover types (bare soil, debris and vegetation) in Nothofagus forests of Tierra del Fuego, according to forest type (deciduous, mixed, or evergreen) and landscape location (coast or mountain)

\begin{tabular}{|c|c|c|c|c|c|c|}
\hline Factor & & Richness & Strata & Bare Soil (\%) & Debris (\%) & Vegetation (\%) \\
\hline \multirow[t]{4}{*}{ Type } & Deciduous & $12.55 \mathrm{~b}$ & $3.6 \mathrm{~b}$ & $16.45 \mathrm{a}$ & 14.70 & $137.5 \mathrm{~b}$ \\
\hline & Mixed & $7.90 \mathrm{a}$ & $2.7 \mathrm{a}$ & $38.80 \mathrm{~b}$ & 17.65 & $63.0 \mathrm{a}$ \\
\hline & Evergreen & $6.65 a$ & $2.9 \mathrm{a}$ & $31.40 \mathrm{~b}$ & 17.30 & 76.8 a \\
\hline & $F(p)$ & $26.29(<0.001)$ & $10.49(<0.001)$ & $11.51(<0.001)$ & $1.14(0.327)$ & $13.04(<0.001)$ \\
\hline \multirow[t]{3}{*}{ Location } & Coast & 8.03 a & $2.7 \mathrm{a}$ & $36.57 \mathrm{~b}$ & 17.27 & $69.0 \mathrm{a}$ \\
\hline & Mountain & $10.03 b$ & $3.4 \mathrm{~b}$ & $21.20 \mathrm{a}$ & 15.83 & $115.9 \mathrm{~b}$ \\
\hline & $F(p)$ & $8.16(0.006)$ & $12.68(<0.001)$ & $15.72(<0.001)$ & $0.68(0.414)$ & $18.91(<0.001)$ \\
\hline Type $\times$ Location & $F(p)$ & $4.92(0.011)$ & 0.47 (0.628) & $0.32(0.730)$ & $0.78(0.462)$ & $0.70(0.503)$ \\
\hline
\end{tabular}

$F(p)=$ Fisher statistic with probability between brackets. Different letters show differences by Tukey test at $p<0.05$

The variable vegetation was $\ln (Y+1)$ transformed for the analysis to accomplish ANOVA assumptions, but not transformed data are shown 
Table 4 Understory ground cover by taxonomic groups in Nothofagus forests of Tierra del Fuego, according to forest type (deciduous, mixed, or evergreen) and landscape location (coast or mountain)

\begin{tabular}{|c|c|c|c|c|c|c|}
\hline Factor & & Lichens (\%) & Bryophytes (\%) & Ferns (\%) & Monocots (\%) & Dicots (\%) \\
\hline \multirow[t]{4}{*}{ Type } & Deciduous & 0.60 & $7.25 \mathrm{a}$ & $10.80 \mathrm{~b}$ & $12.85 b$ & $106.00 \mathrm{~b}$ \\
\hline & Mixed & 0.90 & $19.10 \mathrm{~b}$ & $0.30 \mathrm{a}$ & $3.95 \mathrm{a}$ & $38.75 \mathrm{a}$ \\
\hline & Evergreen & 0.65 & $27.00 c$ & $0.40 \mathrm{a}$ & $3.20 \mathrm{a}$ & $45.55 \mathrm{a}$ \\
\hline & $F(p)$ & $0.41(0.663)$ & $23.22(<0.001)$ & $10.33(<0.001)$ & $14.07(<0.001)$ & $11.04(<0.001)$ \\
\hline \multirow[t]{3}{*}{ Location } & Coast & $1.00 \mathrm{~b}$ & $8.33 \mathrm{a}$ & 6.67 & $2.87 \mathrm{a}$ & $50.10 \mathrm{a}$ \\
\hline & Mountain & $0.43 a$ & $27.23 b$ & 1.00 & $10.47 b$ & $76.77 b$ \\
\hline & $F(p)$ & $5.56(0.022)$ & $67.05(<0.001)$ & $3.34(0.073)$ & $15.96(<0.001)$ & $4.70(0.034)$ \\
\hline Type $\times$ Location & $F(p)$ & $5.46(0.007)$ & $4.34(0.018)$ & $1.57(0.218)$ & $1.46(0.241)$ & $1.47(0.240)$ \\
\hline
\end{tabular}

$F(p)=$ Fisher statistic with probability between brackets. Different letters show differences by Tukey test at $p<0.05$.

Variables were $\ln (Y+1)$ transformed for the analysis, but not transformed data are shown

(percentage index $=11 \%$ in average) than in deciduos forests (percentage index $=6 \%$ ). Monocots had the lowest index in evergreen $(1 \%)$ and the greast index in deciduous $(4 \%)$, with intermediate values for mixed forests, while lichens did not differentiated among forest types (percentage index $=0.5 \%$ in average). On the other hand, bare soil, debris, monocots and lichens presented significantly higher indexes in coast than in mountain. Interactions in bryophyte index occurred by significant differences among deciduos vs. mixed and evergreen forests in mountain (Fig. 2), but only among deciduous and evergreen in coast locations, while fern index was significantly higher in deciduous coast forests than in other forest type and locations.

\section{Understory assemblage patterns}

Ordination graphic by NMS highlighted relations among forest types and locations (Fig. 3), since Axis 1 split between coast and mountain plots, while Axis 2 showed a gradient among deciduous, mixed and evergreen forests, which was more evident in mountain than in coast location. Moreover, the deciduous forests had higher internal variability while mixed and evergreen stands showed less internal variability forming closer groups. MRPP confirmed significant statistical differences between locations $(T=-14.390 ; p<0.001$;
$A=0.087)$, and also, but greater, among forest types ( $T=-$ 18.260; $p<0.001 ; A=0.158)$, with significant differences among all forest type pairwise comparisons $(T<-4.062 ; p$ $<0.004 ; A>0.040)$, where greatest $A(0.193)$ was observed in evergreen vs. deciduous comparison. Likewise, MRPP showed significant differences among combined "forest type-location" ( $T=-20.980 ; p<0.001 ; A=0.296)$, with significant differences among all pairwise comparisons $(T<-3.503 ; p<0.009 ; A>0.080)$, where greatest $A$ (0.328) was observed in coast mixed vs. evergreen mountain comparison.

For DCA analysis, only two ordination axes were retained for interpretation (eigenvalues of 0.5989 for Axis 1 and 0.0267 for Axis 2). These analysis emphasized species association with forest types, with more richness related to deciduous forests than evergreen or mixed forests (Fig. 4). Likewise, there were more species shared only between mixed and deciduous forests (13 species, which did not occur in evergreen forests), than between mixed and evergreen forests (four species, which did not occur in deciduous forests), meanwhile none species were shared only between pure evergreen and deciduous forests. Among the species shared by all forest types, Maytenus disticha appeared as commonly observed in

Table 5 Understory index by groups (bare soil, debris, lichens, bryophytes, ferns, monocots and dicots) in Nothofagus forests, considering forest type (deciduous, mixed or evergreen) and landscape location (coast or mountain)

\begin{tabular}{|c|c|c|c|c|c|c|c|c|}
\hline Factor & & Bare soil & Debris & Lichens & Bryophytes & Ferns & Monocots & Dicots \\
\hline \multirow[t]{4}{*}{ Type } & Deciduous & $12.9 \mathrm{a}$ & $6.0 \mathrm{a}$ & 0.2 & $2.5 \mathrm{a}$ & $2.8 \mathrm{~b}$ & $3.8 \mathrm{~b}$ & 34.5 \\
\hline & Mixed & $26.7 \mathrm{~b}$ & $11.0 \mathrm{~b}$ & 0.7 & $10.7 \mathrm{~b}$ & $0.2 \mathrm{a}$ & $2.4 \mathrm{ab}$ & 25.9 \\
\hline & Evergreen & $33.7 b$ & $10.5 b$ & 0.5 & $13.5 \mathrm{~b}$ & $0.2 \mathrm{a}$ & $1.4 \mathrm{a}$ & 28.4 \\
\hline & $F(p)$ & $10.22(<0.001)$ & $6.24(0.004)$ & $1.92(0.157)$ & $29.74(<0.001)$ & $4.60(0.014)$ & $3.88(0.027)$ & $2.53(0.089)$ \\
\hline \multirow[t]{3}{*}{ Location } & Coast & $32.2 b$ & $11.0 \mathrm{~b}$ & $0.8 \mathrm{~b}$ & $5.4 \mathrm{a}$ & $2.0 \mathrm{~b}$ & $1.5 \mathrm{a}$ & 30.5 \\
\hline & Mountain & $16.7 \mathrm{a}$ & $7.4 \mathrm{a}$ & $0.1 \mathrm{a}$ & $12.5 \mathrm{~b}$ & $0.1 \mathrm{a}$ & $3.5 \mathrm{~b}$ & 28.7 \\
\hline & $F(p)$ & $16.36(<0.001)$ & $7.54(0.008)$ & $11.75(0.001)$ & $34.66(<0.001)$ & $6.00(0.018)$ & $7.52(0.008)$ & $0.33(0.570)$ \\
\hline Type $\times$ Location & $F(p)$ & $0.19(0.830)$ & $0.40(0.669)$ & $1.57(0.216)$ & $10.62(<0.001)$ & $4.63(0.014)$ & $1.17(0.319)$ & $1.14(0.327)$ \\
\hline
\end{tabular}

$F(p)=$ Fisher statistic with probability between brackets. Different letters show differences in Tukey test at $p<0.05$

The values are expressed as percentage 


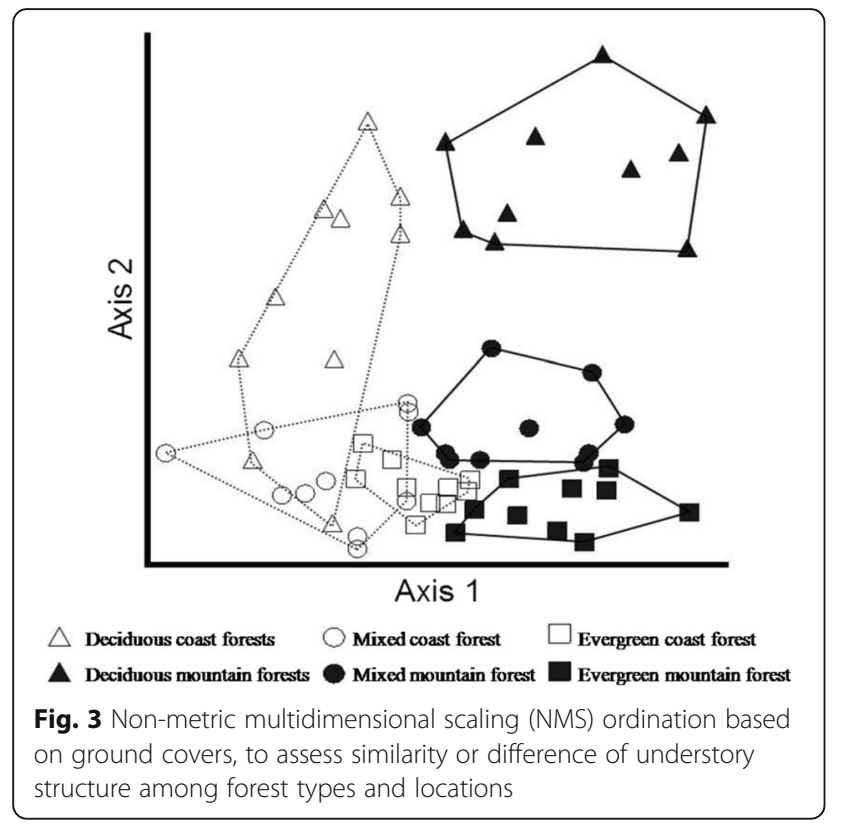

any of them, while $R$. geoides is more related to evergreen forests, $P$. alopecurus to mixed forests, and $N$. pumilio, Senecio acanthifolius, Codonorchis lessoni, Gunnera magellanica, Blechnum penna-marina and Macrachaenium gracile are more associated to deciduous forests. Different life forms were distributed in all forest types, but erect herbs were more abundant in deciduous forests.

Indicator species analysis showed seven indicator species for deciduous forests (Table 6), of which five species did not occurred exclusively in this forest type (Fig. 4), complemented with six detector species. Meanwhile, evergreen forests presented only two indicator and one detector species, and there was not detector or indicator species for mixed forests. Likewise, one indicator and two detector species were found in coastal sites, and four indicator and four detector species were found at mountain locations (Table 6).

\section{Discussion}

The three forest types investigated in this study differed in overstory tree composition and the selected forest structure variables (Table 1). Regarding solar radiation variables, it is known that beech crowns transmit only a small proportion of daylight to the forest floor (Ellenberg 1996; Barbier et al. 2008) and that the effective amount of radiation reaching the forest floor is determined by forest structural characteristics and tree species (van Oijen et al. 2005; Barbier et al. 2008; Promis et al. 2008; Martínez Pastur et al. 2012; Kuninaga et al. 2015). According with this, we expected the highest level of solar radiation in deciduous forest, because the canopy of $N$. pumilio is quite sparse and their leaves are substantially thinner than $N$. betuloides. However, we were unable to detect differences in solar radiation between deciduous and evergreen forests (Table 1), probably due to we taken hemispherical photos during summer but assumed the same (uniform) amount of canopy cover during the entire growing season for all forest types. A month-bymonth analysis would give us a better idea of the monthly differences in solar radiation due to the dynamics of canopies throughout the year (Promis et al. 2010) mainly in deciduous and mixed forests.

Our study showed that canopy-layer composition influences the understory structure and composition (Tables 3 and 4; Figs. 3 and 4). While mixed forests have greater similarity to evergreen forests in the understory structural

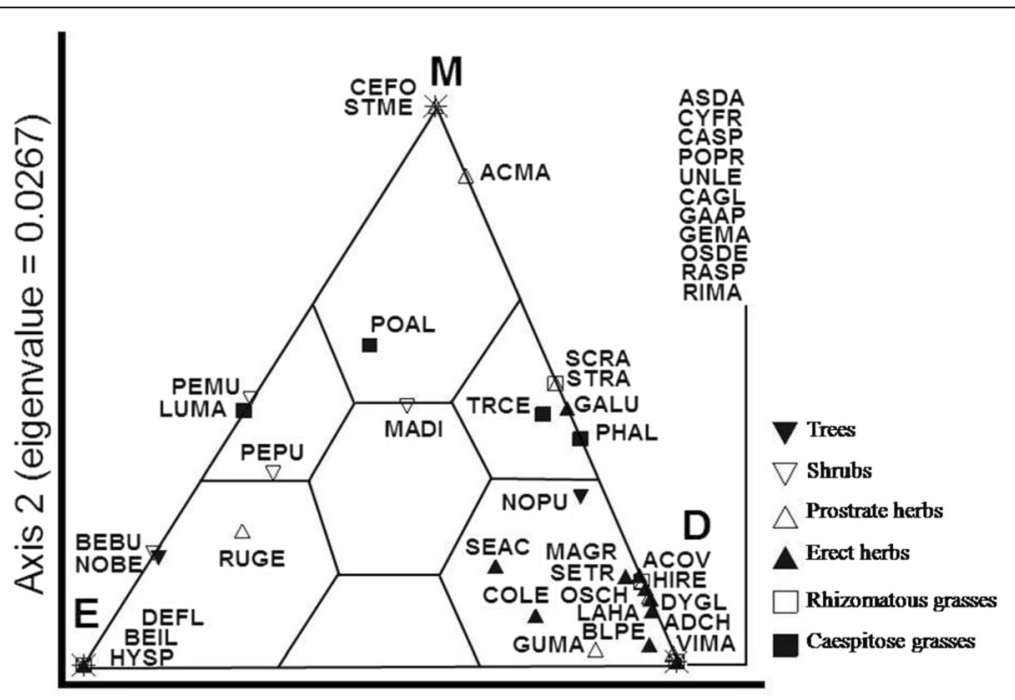

Axis 1 (eigenvalue $=0.5989$ )

Fig. 4 Detrended correspondence analysis (DCA) based on vascular plant species cover and life forms in Nothofagus forests. Species codes are in Additional file 1 
Table 6 Indicator species analysis (IndVal and probability between brackets) of understory vascular plant species, for each Nothofagus forest type and landscape location

\begin{tabular}{|c|c|c|c|c|c|}
\hline \multirow{2}{*}{$\begin{array}{l}\text { Species } \\
\text { code }\end{array}$} & \multicolumn{3}{|l|}{ Forest type } & \multicolumn{2}{|l|}{ Locations } \\
\hline & Deciduous & Mixed & Evergreen & Coast & Mountain \\
\hline DYGL & $84.0(<0.001)$ & & & & \\
\hline $\mathrm{ADCH}$ & $72.4(<0.001)$ & & & & \\
\hline COLE & $60.6(<0.001)$ & & & & \\
\hline NOPU & $66.3(<0.001)$ & & & & \\
\hline VIMA & $59.1(<0.001)$ & & & & \\
\hline OSDE & $55.0(<0.001)$ & & & & \\
\hline$C A G L$ & $50.0(<0.001)$ & & & & \\
\hline MAGR & $41.2(0.007)$ & & & & $66.4(<0.001)$ \\
\hline BLPE & $32.7(0.012)$ & & & $29.4(0.014)$ & \\
\hline $\mathrm{OSCH}$ & $26.1(0.014)$ & & & & \\
\hline HIRE & $25.7(0.015)$ & & & & $26.7(0.004)$ \\
\hline GAAP & $25.0(0.009)$ & & & & \\
\hline GUMA & $25.5(0.025)$ & & & & $36.7(<0.001)$ \\
\hline PEPU & & & $35.1(0.0039)$ & & $70.1(<0.001)$ \\
\hline RUGE & & & $54.1(<0.001)$ & & $67.6(<0.001)$ \\
\hline NOBE & & & $79.5(<0.001)$ & & \\
\hline PEMU & & & & $35.9(0.002)$ & \\
\hline MADI & & & & $70.0(<0.001)$ & \\
\hline SEAC & & & & & $56.7(<0.001)$ \\
\hline TRCE & & & & & $31.9(0.003)$ \\
\hline LUMA & & & & & $26.7(0.006)$ \\
\hline Total & $7(6)$ & $0(0)$ & $2(1)$ & $1(2)$ & $4(4)$ \\
\hline
\end{tabular}

Species codes are in the Additional file 1. Indicator species are shown in bold, while detector species are in normal font

features, deciduous and mixed were similar in terms of the specific composition of plant assemblage. This could show deciduous and evergreen species differentially influence the understory communities beyond the simple comparison of the identity of plant species.

In other forest ecosistems, the authors conclude that mixedwood forest may facilitate higher diversity and/or richness by providing a heterogeneous understory environment allowing the co-existence of common shade tolerant species along with resource-demanding, shade intolerant species and generalist species in patches with a mixed tree composition (Chavez and Macdonald 2012; Yu and Sun 2013). However, and contrary to our hypothesis, mixed broadleaved forests did not increase plant diversity at understory level compared to pure forests. We found maximum richness and vegetation cover in pure deciduos forests, not in mixed stands (Tables 3 and 4; Fig. 4). Mixing of deciduous and evergreen tree species generate an intermediate level of plant diversity (richness and cover) derived from the mixture of shared plants, many of these herbs
(Macrachaenium gracile, Senecio acanthifolius) shrubs (Maytenus disticha, Rubus geoides) or Nothofagus seedlings that grow under a closed canopy regardless of the canopy composition. In a review work, Barbier et al. (2008) concluded that mixing of deciduous and coniferous tree species generally affects understory diversity, but in almost all cases maximum diversity is observed in one of the pure stands, not in mixed stands. It is important to note that most of the current evidence about overstory-understory interactions in mixed forest derived from mixed-wood forests (deciduous broadleaf and conifer) of northern hemisphere. On the opposite side, the coverage of bryophytes group on the forest floor was improved in evergreen stands likely by lower competition with vascular plants for water and light at understory level (Gallo et al. 2013). The light-sensitivity of bryophytes is supported by other field studies as well (Tinya and Ódor 2016).

Our results confirm the presence of exclusive species in pure forests (deciduous or evergreen) and landscape locations, and this species could indicate particular characteristics of each pure forest type (Table 6). Some common understory species on evergreen forests are also perennial species (e.g., Gaultheria mucronata, Maytenus disticha), which could have some independence from environmental fluctuations because they have better nutrient retention over time (e.g., $N$. betuloides can retain seven years a leaf in the tree) and can develop in poor content nutrient habits (Donoso and Donoso 2006; Promis et al. 2008). The understory of deciduous Nothofagus forest is dominated by herbaceous plants associated with frequent small-scalle disturbances (e.g., gap formation) or a more dynamic than the evergreen forest canopy (Lencinas et al. 2008b, 2011; Promis et al. 2010). The connection between deciduous and mixed forests is given by the presence and abundance of herbaceous species (e.g., Dysopsis glechomoides, Gavilea lutea, Viola magellanica) that naturally grown under closed canopies but benefiting from smallscale disturbances at canopy level. Microclimatic conditions could varies more widely in deciduous and mixed forest stands than in evergreen stands, in response to the annual gradient of light, influencing soil properties (Gazol and Ibáñez, 2010; Yu and Sun 2013; Márialigeti et al. 2016). This generates more diverse site conditions over short distances and thus more habitat opportunities for a wide variety of plants.

Other authors highlight the importance of canopyspecies leaf litter as a key factor influencing soil acidity and thereby nutrient stocks, whereas the upper $10 \mathrm{~cm}$ of soil are most significantly influenced by tree-species effects (Nordén 1994; Finzi et al. 1998; Augusto et al. 2002, 2003). Additionally, thickness of litter layer varies according to tree species (Neirynck et al. 2000; Augusto et al. 2002; van Oijen et al. 2005). A close positive correlation between soil $\mathrm{pH}$ and herb-layer diversity (e.g. Härdtle et 
al. 2003; Ferretti et al. 2006; Barbier et al. 2008), as well as litter layer thinness (e.g. Borchsenius et al. 2004; van Oijen et al. 2005; Barbier et al. 2008) was particularly detected in forests dominated by beech, a group of trees which produces less decomposable and acidifying litter (Ellenberg 1996). However, our study did not include nutrient composition of forest soils neither the litter input from different canopies, but major contribution of the deciduous Nothofagus species in mixed stands (i.e., highest proportion of basal area and tree density of deciduous species) may evidence major input of litterfall from deciduos species and therefore a strong influence on plant species assemblage.

Regarding landscape locations, we found that understory structural and compositional patterns between pure and mixed forest are maintained in coast and mountain, except in richness, lichen and bryophytes cover, where we found interactions (Fig. 2). As mountain forests grown under more stressful conditions, (e.g., extreme temperature values, shorter growing season) than coastal forests, at similar latitude greater diversity would be expected in the later one (Lencinas et al. 2008b). Contrary to this idea, we found that landscape location have an important effect over forest type and understory composition, showing that mountain was more diverse (e.g., higher richness, strata quantity and vegetation cover) than coast, which could be due to a lowest content of litter in the coast as was described by Frangi et al. (2005) in evergreen forests floors considered less fertile. Moreover, the steepest slopes of mountain sites determines more frequent small-scale disturbances than coastal sites with gentle slopes (Roig 1998) generating greater microenvironmental heterogeneity. Following the environmental heterogeneity hypothesis (Huston 1994), small-scale environmental differences result in increased herb-layer diversity. Related to this hypothesis, we found some evidence (pers. obs.) indicating a more dynamic stand structure in mountain than in costal forests. In example, we observed big trees fallen over more than 50 years ago and dense groups of Nothofagus saplings (advanced regeneration) in deciduos and mixed stands on mountains, meanwhile the forest structure on the coast seems to be more stable and with recent fallen trees. These recent disturbances determines less stability of forest soil (e.g., removal of the organic layer, exposed rocks, etc.) generating a poorest and nonstable understory in coastal sites compared to more stable conditions after older disturbances in mountain forests. However, more detailed studies are necessary to understand the effect of landscape location on understory species assemblages including a wide range of geographical locations and other landscape metrics (e.g., forest patch size).

The understanding of the interaction of overstory and understory species was key under future climate change. At these high latitudes, tree growth and distribution is most sensitive to climatic conditions (Hertel et al. 2008; Massaccesi et al. 2008; Ivancich et al. 2012), and therefore, a shift in plant communities forced by climate change would be more evident. In Southern Patagonia, the maximum temperature and annual precipitation are predicted to increase until the end of the twenty-first century, possibly leading to a higher net primary productivity (Kreps et al. 2012). This could cause a change on vegetation composition between coast and mountain forests, since exclusive plants of mountain forests are adapted to colder and dryer conditions. On the other hand, higher net primary productivity would produce important changes on soil properties, driving a shift in the proportion of deciduous and evergreen and therefore on understory communities.

\section{Conclusions}

We conclude that canopy-layer composition influences the herb-layer structure and diversity in two different ways: the presence of the evergreen component in mixed stands determines structural features at understory level, while the deciduous component determines the specific composition of plant assemblage. The deciduos forests were the most diverse and had higer number of exclusives species compared to mixed and evergreen forests. Lack of indicator species exclusive of mixed forest support it as transitional habitat where both evergreen and deciduous communities meet and integrate.

At the same time, our results indicates that landscape has a major influence on the structure, diversity and richness of understory vegetation of pure and mixed forests mainly associated to the magnitude and frequency of natural disturbances. Moreover, we want to stress that mountain forest not only had higher herb-layer diversty but also more species exclusive of such habitat. Our study suggests that mixed Nothofagus forest provide suitable habitat for both pure deciduous and pure evergreen understory plant species and different assemblages in coastal and mountain sites. To better understand the light effects on interactions overstory-understory, we consider that a month-by-month analysis is necessary in a next research phase. We proposed that maintaining the mixture of canopy patch types within mixed stands will be important for conserving the natural patterns of understory plant composition in southern beech mixed forests.

\section{Additional file}

Additional file 1: List of vascular plant species observed in the understory of deciduous, mixed and evergreen Nothofagus forests of Tierra del Fuego, with occurrence frequency (\%) in each forest type. (DOCX $31 \mathrm{~kb})$

\section{Acknowledgements}

The authors gratefully thank the Administración de Parques Nacionales and the staff of Tierra del Fuego National Park. Project APN-1236 supported this research during 2013-2014. 


\section{Authors' contributions}

MVL and GMP conceived the idea. LM, RS GMP and MVL conducted the field work and statistical analyzes. MTM and AHH made figures and analyzed the bibliography. All authors analyzed the bibliography and contributed to the discussion of the results and wrote the manuscript. All authors read and approved the final manuscript.

\section{Competing interests}

The authors declare that they have no competing interests.

\section{Field permits}

Research permissions to sample understory plants at Tierra del Fuego National Park and Garibaldi were provided by the Administración de Parques Nacionales (Project APN-1236) and the local authority of Environment and Sustainable Development (S.D.S.yA. № 0155/2015), respectivelly.

Received: 29 September 2016 Accepted: 10 May 2017 Published online: 17 May 2017

\section{References}

Allué CJ, Arranz A, Bava JO, Beneitez JM, Collado L, García-López JM (2010) Caracterización y cartografía fitoclimáticas del bosque nativo subantártico en la Isla Grande de Tierra del Fuego (Patagonia, Argentina). For Syst 2:189-207 Augusto L, Ranger J, Binkley D, Rothe A (2002) Impact of several common tree species of European temperate forests on soil fertility. Ann For Sci 59:233-253

Augusto L, Dupouey JL, Ranger J (2003) Effects of tree species on understory vegetation and environmental conditions in temperate forests. Ann For Sci 60:823-831

Barbier S, Gosselin F, Balandier P (2008) Influence of tree species on understory vegetation diversity and mechanisms involved. A critical review for temperate and boreal forests. For Ecol Manage 254:1-15

Bitterlich W (1984) The relascope idea. Relative measurements in forestry. CAB Londres, England

Borchsenius F, Nielsen PK, Lawesson JE (2004) Vegetation structure and diversity of an ancient temperate deciduous forest in SW Denmark. Plant Ecol 175:121-135

Brancaleoni L, Strelin J, Gerdol R (2003) Relationship between geomorphology and vegetation patterns in subantarctic Andean tundra of Tierra del Fuego. Polar Biol 26:404-410

Bruce MC, Mefford MJ (1999) PC-ORD: multivariate analysis of ecological data. MJM Software Design, Oregon

Chavez V, Macdonald SE (2012) Partitioning vascular understory diversity in mixedwood boreal forests: the importance of mixed canopies for diversity conservation. Fore Ecol Manage 271:19-26

Correa MN (1969-1998) Flora Patagónica. Colección Científica INTA Tomo 8. Partes II, III, IVb, V, VI y VII. Buenos Aires.

Cruz G, Ibarra M, Promis A, Cabello G (2007) Tipos de bosques, estructura y dinámica natural. In: Cruz G, Caldentey J (eds) Caracterización, silvicultura y uso de los bosques de coihue de Magallanes (Nothofagus betuloides (Mirb.) Blume) en la XII Región de Chile. Icaro Editions, Santiago, Chile

Dale VH, Beyeler SC, Jackson B (2002) Understory vegetation indicators of anthropogenic disturbance in longleaf pine forests at Fort Benning, Georgia, USA. Ecol Indic 1:155-170

Damascos MA (1996) Patrones morfologicos y floristicos en los bosques andinopatagónicos de Argentina. Ecol Aust 6:94-100

Donoso CZ, Donoso P (2006) Nothofagus betuloides (Mirb) Oerst. In: Donoso Zegers C (ed) Las especies arbóreas de los bosques templados de Chile y Argentina autoescología. Marisa Cuneo Ediciones, Valdivia

Dreiss LM, Volin JC (2013) Influence of leaf phenology and site nitrogen on invasive species establishment in temperate deciduous forest understories. For Ecol Manage 296:1-8

Dufrêne M, Legendre P (1997) Species assemblages and indicator species: the need for a flexible asymmetrical approach. Ecol Monog 67:345-366

Ellenberg H (1996) Vegetation Mitteleuropas mit den Alpen in okologischer Sicht. 5th edition. Ulmer, Stuttgart.

Ferretti M, Calderisi M, Amoriello T, Bussotti F, Canullo R, Campetella G, Costantini A, Fabbio G, Mosello R (2006) Factors influencing vascular species diversity in the CONECOFOR permanent monitoring plots. Ann Inst Sper Selv 30:97-106

Finzi AC, Canham CD, van Breemen N (1998) Canopy tree-soil interactions within temperate forests:species effects on pH an cations. Ecol Appl 8(2):447-454
Forrester DI, Bonal D, Dawud S, Gessler A, Granier A, Pollastrini M, Grossiord C (2016) Drought responses by individual tree species are not often correlated with tree species diversity in European forests. J Appl Ecol 53:1725-1734

Frangi JL, Barrera MD, Puigdefábregas J, Yapura PF, Arambarri AM, Richter L (2005) Ecología de los bosques de Tierra del Fuego. In: Arturi MF, Frangi JL, Goya JF (eds) Ecología y manejo de los bosques de la Argentina. Universidad Nacional de La Plata, Argentina

Frazer GW, Fournier RA, Trofymow JA, Gall RJ (2001) A comparison of digital and film fisheye photography for analysis of forest canopy structure and gap light transmission. Agric For Meteorol 109:249-263

Gallo EA, Lencinas MV, Martínez Pastur G (2013) Site quality influence over understory plant diversity in old-growth and harvested Nothofagus pumilio forest. For Syst 22:25-38

Gazol A, Ibáñez R (2010) Scale-specific determinants of a mixed beech and oak seedling-sapling bank under different environmental and biotic conditions. Plant Eco 211(1):37-48

Gilliam FS (2007) The ecological significance of the herbaceous layer in temperate forest ecosystems. Bioscience 57:845-858

Gracia M, Montané F, Piqué J, Retana J (2007) Overstory structure and topographic gradients determining diversity and abundance of understory shrub species in temperate forests in central Pyrenees (NE Spain). For Ecol Manage 242:391-397

Härdtle W, Oheimb G, von Westphal C (2003) The effects of light and soil conditions on the species richness of the ground vegetation of deciduous forests in northern Germany (Schleswig-Holstein). For Ecol Manage 182:327-338

Hertel D, Therburg A, Villalba R (2008) Above- and below-ground response by Nothofagus pumilio to climatic conditions at the transition from the steppeforest boundary to the alpine treeline in southern Patagonia, Argentina. Plant Ecol Divers 1(1):21-33

Huston MA (1994) Biological diversity. The coexistence of species on changing landscapes. Cambridge University Press, Cambridge, p 708

Ivancich H, Martínez Pastur G, Roig F, Barrera M, Pulido F (2012) Changes in height growth patterns in the upper treeline forests of Tierra del Fuego in relation to climate change. Bosque 33(3):267-270

Kreps G, Martínez Pastur G, Peri P (2012) Cambio climático en Patagonia sur. Escenarios futuros en el manejo de los recursos naturales. Ediciones INTA, Buenos Aires.

Kudo G, Ida TY, Tani T (2008) Linkages between phenology, pollination, photosynthesis, and plant reproduction in deciduous forest understory plants. Ecology 89(2):321-331

Kuninaga T, Hirayama K, Sakimoto M (2015) Negative canopy-understorey interaction shapes the sapling bank of Fagus crenata in a cool-temperate, conifer-hardwood mixed forest. Plant Ecol 216:1191-1202

Lencinas MV, Martínez Pastur G, Solán R, Gallo E, Cellini JM (2008a) Forest management with variable retention impact over bryophyte communities of Nothofagus pumilio understory. Forstarchiv 79:77-82

Lencinas MV, Martínez Pastur G, Rivero P, Busso C (2008b) Conservation value of timber quality versus associated non-timber quality stands for understory diversity in Nothofagus forests. Biodivers Conserv 17:2579-2597

Lencinas MV, Martínez Pastur G, Gallo E, Cellini JM (2011) Alternative silvicultural practices with variable retention to improve understory plant diversity conservation in southern Patagonian forests. For Ecol Manage 262:1236-1250

Márialigeti S, Tinya F, Bidló A, Odor P (2016) Environmental drivers of the composition and diversity of the herb layer in mixed temperate forests in Hungary. Plant Ecol 217:549-563

Martínez Pastur G, Peri PL, Fernández MC, Stafieri G, Lencinas A (2002) Changes in understory species diversity during the Nothofagus pumilio forest management cycle. J For Res 7(3):2-10

Martínez Pastur G, Cellini JM, Lencinas MV, Barrera M, Peri PL (2011) Environmental variables influencing regeneration of Nothofagus pumilio in a system with combined aggregated and dispersed retention. For Ecol Manage 261:178-186

Martínez Pastur G, Jordán C, Lencinas MV, Soler R, Ivancich H, Kreps G (2012) Landscape and microenvironmental conditions influence over regeneration dynamics in old-growth Nothofagus betuloides Southern Patagonian forests. Plant Biosyst 146:201-213

Massaccesi G, Roig F, Martínez Pastur G, Barrera M (2008) Growth patterns of Nothofagus pumilio trees along altitudinal gradients in Tierra del Fuego, Argentina. Trees 22(2):245-255

Matteri C, Schiavone M (2002) Catálogo de los musgos (Bryophyta) de la región Fueguina en Argentina y Chile. Revista del Museo Argentino de Ciencias Naturales 4:111-138 
McCune B, Grace JB (2002) Analysis of ecological communities. MJM Software Design, Oregon

Mittermeier RA, Mittermeier CG, Brooks TM, Pilgrim JD, Konstant WR, da Fonseca GAB, Kormos C (2003) Wilderness and biodiversity conservation. PNAS 100(18):10309-10313

Moore D (1983) Flora of Tierra del Fuego. Anthony Nelson, England, Missouri Botanical Garden, USA

Neirynck J, Mirtcheva S, Sioen G, Lust N (2000) Impact of Tilia platyphyllos Scop., Fraxinus excelsior L., Acer pseudoplatanus L., Quercus robur L. and Fagus sylvatica $L$. on earthworm biomass and physico-chemical properties of a loamy soil. For Ecol Manage 133:275-286

Nordén U (1994) Influence of broad-leaved tree species on pH and organic matter content of forest topsoils in Scania, South Sweden. Scand J For Res 9:1-8

Promis A, Cruz G, Reif A, Gärtner S (2008) Nothofagus betuloides (MIRB.) OERST 1871 (Fagales: Nothofagaceae) forests in southern Patagonia and Tierra del Fuego. Ann Inst Pat 36:53-68

Promis A, Gartner S, Reif A, Cruz G (2010) Effects of natural small-scale disturbances on below-canopy solar radiation and regeneration patterns in an old-growth Nothofagus betuloides forest in Tierra del Fuego, Chile. Allg Forst Jagdztg 181(3/4):53-64

Roig F (1998) La vegetación de la Patagonia. In: Correa M (ed) Flora Patagónica. INTA Colección Científica, Buenos Aires

Simonson WD, Allen HD, Coomes DA (2014) Overstorey and topographic effects on understories: evidence for linkage from cork oak (Quercus suber) forests in southern Spain. For Ecol Manage 328:35-44

Spyreas G, Matthews JW (2006) Floristic conservation value, nested understory floras, and the development of second-growth forest. Ecol Applic 16:1351-1366

Tejeda-Cruz C, Mehltreter K, Sosa VJ (2008) Indicadores ecológicos multitaxonómicos, p. 271-278. In: Manson RH, Hernández-Ortiz V, Gallina S, Mehltreter K (eds). Agroecosistemas cafetaleros de Veracruz: Biodiversidad, manejo y conservación. Instituto de Ecología e Instituto Nacional de Ecología, México.

Tinya F, Odor P (2016) Congruence of the spatial pattern of light and understory vegetation in an old-growth, temperate mixed forest. For Ecol Manage 381:84-92

Tuhkanen S (1992) The climate of Tierra del Fuego from a vegetation geographical point of view and its ecoclimatic counterparts elsewhere. Acta Bot Fenn 145:64

Van Oijen M, Rougier J, Smith R (2005) Bayesian calibration of process- based forest models: bridging the gap between models and data. Tree Physiol 25:915-927

Veblen TT, Ashton DH, Schlegel FM, Veblen AT (1978) Influencia del estrato arbóreo sobre los estratos inferiores en un bosque, mixto, perennicaducifolio de Antillanca, Osorno, Chile. C. D. Oxf:. 182.4. Bosque 2(2):88-104

Veblen TT, Veblen AT, Schlegel FM (1979) Understorey patterns in mixed evergreen-deciduous Nothofagus forests in Chile. J Ecol 67(3):809-823

Yu M, Sun OJ (2013) Effects of forest patch type and site on herb-layer vegetation in a temperate forest ecosystem. Fore Ecol Manage 300:14-20

\section{Submit your manuscript to a SpringerOpen ${ }^{\odot}$ journal and benefit from:}

- Convenient online submission

- Rigorous peer review

Open access: articles freely available online

- High visibility within the field

- Retaining the copyright to your article

Submit your next manuscript at $\boldsymbol{\nabla}$ springeropen.com 